Volume $22 \quad$ Nomor 1, Januari 2021

Halaman 49-56

URL: https://jurnal.unej.ac.id/index.php/SEMIOTIKA/index

E-ISSN: 2599-3429

P-ISSN: $1411-5948$

\title{
ANALISIS FRASA BERDASARKAN KESETARAAN DISTRIBUSI \\ PADA TAJUK RENCANA SOLOPOS "KONSOLIDASI DAN PEMBERDAYAAN ORGANISASI MASYARAKAT SIPIL"
}

\section{PHRASE ANALYSIS BASED ON EQUALITY OF DISTRIBUTION ON THE SOLOPOS HEADLINES "UNIFICATION AND EMPOWERMENT OF CIVIL SOCIETY ORGANIZATIONS"}

\author{
Latifah Ayu Widyaningsih* \\ Prodi Pendidikan Bahasa dan Sastra Indonesia, Fakultas Bahasa dan Seni \\ Universitas Negeri Semarang \\ *Corresponding Author: latifahwidyaningsih09@gmail.com \\ Informasi Artikel:
}

Dikirim: 6/1/2021; Direvisi: 14/1/ 2021; Diterima: 27/1/ 2021

\begin{abstract}
In research, the main focus is the use of phrases. A phrase is a linguistic unit that has nonpredicative properties or can be called a variety that occupies a function in language syntax. Phrases based on the equality of distribution are divided into two types. They are endocentric phrases and exocentric phrases. This paper aims to describe words classified as endocentric and exocentric phrases and the structure of these phrases, in this study using a descriptive analysis method, conducted to obtain information about the inner sign at time of this research can systematically check the data. This study proves that there are endocentric and exocentric phrases and found forming phrases structure at the headlines of Solopos newspaper.
\end{abstract}

Keywords: headlines, phrases, endocentric phrases, exocentric phrases, analysis structure.

\begin{abstract}
Abstrak
Fokus penelitian ini adalah penggunaan frasa. Frasa adalah satuan linguistik yang merupakan gabungan kata memiliki sifat nonpredikatif atau bisa disebut juga merupakan gabungan yang menduduki fungsi pada sintaksis bahasa. Frasa berdasarakan kesetaraan distribusinya dibagi menjadi dua jenis yaitu frasa endosentrik dan frasa eksosentrik. Tujuan penulisan ini untuk mendeskripsikan kata yang tergolong frasa endosentrik dan eksosentrik dan struktur pada frasa tersebut. Penelitian ini menggunakan metode deskriptif analisis, yakni penelitian yang dilakukan untuk memperoleh informasi mengenai tanda pada saat penelitian ini dilakukan sehingga dapat memeriksa data secara sistematis. Hasil penelitian menunjukkan bahwa terdapat frasa endosentrik dan frasa eksosentrik, serta struktur pembentuk frasa pada tajuk berita dalam surat berita Solopos.
\end{abstract}

Kata kunci: tajuk berita, frasa, frasa endosentrik, frasa eksosentrik, analisis, struktur. 


\section{PENDAHULUAN}

Linguistik adalah bidang ilmu bahasa yang menjadikan bahasa sebagai objek utama kajian (Melani, dkk, 2019). Bahasa adalah sebuah sistem, dan kemudian dibentuk dari suatu aturan tertentu, kaidah atau pola-pola dalam bidang bunyi, bentuk, dan kalimat. Bahasa dipergunakan manusia untuk berkomunikasi dan untuk mengidentifikasi diri (Ramadhani, 2018).

Koran atau surat berita adalah salah satu media massa cetak yang memuat laporan kejadian, opini, dan berita aktual yang terjadi. Penggunaan bahasa tulis sangat memperhatikan kelengkapan struktur kebahasaan (Sudiarni, 2012). Tulisan yang dimuat dalam media cetak harus memperhatikan kaidah kebahasaan Indonesia yang berlaku sekarang. Pada kedudukan sintaksis, kata adalah satuan paling kecil secara hierarki yang menjadi elemen pembentuk elemen yang lebih besar, yaitu frasa, klausa, wacana (Nisa, 2018). Frasa di sini adalah salah satu unsur yang mengisi fungsi dalam kalimat yang membangun sebuah wacana dalam berita surat kabar Solopos. Sebuah frasa biasanya terdiri atas dua kata, dan tidak melebihi fungsifungsi yang terdapat pada elemen klausa. Frasa pada umunya terbentuk dari gabungan kata yang memiliki keterkaitan, apabila dua kata tersebut disatukan menjadi memiliki makna baru. Ningsih (2016) menyatakan bahwa frasa memiliki dua karakteristik umum, yakni: (1) frasa adalah gabungan dua kata atau lebih yang memiliki keterkaitan, (2) frasa adalah satuan sintaksis yang tidak lebih dari batas fungsional elemen klausa, jadi frasa terdapat pada salah satu fungsi tertentu di antara $\mathrm{S}, \mathrm{P}, \mathrm{O}, \mathrm{K}$.

Frasa berdasarkan kesetaraan distribusinya dibagi menjadi dua yaitu frasa endosentrik dan frasa eksosentrik. Frasa endosentrik merupakan frasa yang memiliki distribusi kata yang sama dengan elemen, baik semua unsurnya maupun salah satu dari elemen-elemenya (Ramlan, 2005). Golongan frasa endosentrik dibagi menjadi tiga golongan, yaitu frasa endosentrik koordinatif, frasa endosentrik atributif, dan frasa endosentrik apositif (Ramlan, 2005). Frasa eksosentrik mengacu pada bentuk frasa yang komponen-komponennya tidak memiliki perilaku tata bahasa sintaksis secara keseluruhannya. Golongan frasa eksosentrik dibagi menjadi dua golongan, yaitu frasa eksosentrik direktif dan frasa eksosentrik non-direktif. Frasa eksosentrik direktif adalah frasa yang menggunakan perangkai berupa preposisi. Frasa preposisional seluruhnya tidak berperilaku sama dengan komponen-komponennya, baik dengan preposisinya maupun dengan sumbunya. Frasa eksosentrik terdapat dua macam yaitu frasa eksosentrik direktif dan frasa eksosentrik non-direktif. Sakinah (2017 dalam penelitian terhadap koran Fajar menemukan frasa endosentrik koordinatif, frasa endosentrik atributif dan frasa endosentrik apositif.

Artikel ini mengkaji mengenai frasa yang terdiri atas dua macam frasa endosentrik dan frasa eksosentrik, serta analisis struktur frasa dalam koran Solopos. Masalah yang dibahas dalam artikel ini yaitu mengenai penggolongan frasa endosentrik dan frasa eksosentrik, serta jenis kata yang tergolong frasa endosentrik dan frasa eksosentrik. Dalam artikel ini juga dibahas mengenai struktur yang terdapat dalam pembentukan frasa endosentrik dan frasa eksosentrik. Penelitian ini merupakan salah satu cara untuk mengurangi kesalahan sintaksis yang sering terjadi, terutama dalam bidang frasa, sehingga kualitas kebahasaan pada surat kabar semakin baik. 


\section{METODE}

Metode penelitian yang digunakan adalah metode deskriptif dengan teknik kualitatif. Metode ini digunakan untuk mendeskripsikan golongan frasa endosentrik dan eksosentrik, serta mendeskripsikan struktur yang terdapat pada frasa endosentrik dan frasa eksosentrik (Bastian, 2018). Deskripsi dilakukan berdasarkan pengamatan terhadap Tajuk Rencana Solopos.

Sumber data dalam penelitian ini adalah surat kabar Solopos edisi 29 September 2020 pada Tajuk Rencana yang berjudul "Konsolidasi dan Pemberdayaan Organisasi Masyarakat Sipil”. Peneliti menemukan 15 satuan bahasa yang tergolong frasa pada tajuk tersebut.

Analaisis data dilakukan dengan cara menerapkan teknik delesi dan teknik substitusi. Rahayu (2019) menyatakan bahwa teknik delesi dapat diterapkan dalam pendistribusian elemen-elemen frasa endosentrik dan frasa eksosentrik terhadap kedudukan sebuah kalimat yang akan membentuk suatu wacana. Teknik substitusi diterapkan untuk meneliti elemen unsur frasa dalam kalimat yang memiliki kedudukan distribusi yang sama pada elemen satu dengan lainnya.

Teknik catat juga digunakan dengan langkah-langkah sebagai berikut: (1) mengidentifikasi data dengan menggunakan analisis yang berulang-ulang pada wacana berita yang setiap kalimat berisikan frasa endosentrik dan frasa eksosentrik, (2) mencatat setiap kalimat yang tergolong dalam frasa endosentrik dan frasa eksosentrik, (3) memilah dan memilih frasa endosentrik dan frasa eksosentrik dengan memperhatikan kata hubung dan/atau kalimat pada Tajuk Rencana berita, (4) mengklasifikasi frasa endosentrik dan frasa eksosentrik ke dalam tabel, (5) menganalisis golongan frasa endosentrik dan frasa eksosentrik serta struktur yang digunakan pada frasa tersebut.

\section{HASIL DAN PEMBAHASAN}

Dalam sintaksis sebuah wacana utuh tersusun dari kata yang akan membentuk frasa, kemudian frasa akan membentuk klausa, dan klausa akan membentuk kalimat yang selanjutnya menjadi sebuah wacana (Suhardi, 2013). Struktur frasa berarti susunan atau pola yang mengisi sebuah fungsi frasa. Frasa kesetaraan distribusi terdapat dua macam, yakni frasa endosentrik dan frasa eksosentrik. Maharani (2020) menyatakan bahwa frasa endosentrik adalah gabungan kata yang memiliki keseluruhan komponennya dalam tataran sintaksis yang sama dengan unsur-unsur pembentuk kata, baik semua unsur maupun salah satu unsur. Kesetaraan elemen tersebut terdapat dalam sebuah kalimat dan dapat dikaitkan dengan kemungkinan elemenelemen tersebut yang dihubungkan dengan kata penghubung seperti dan atau atau. Dinyatakan pula bahwa frasa endosentrik koordinatif dan frasa endosentrik atributif adalah frasa yang memiliki salah satu inti, yang dapat didahului atau diikuti dengan modifikator. Dalam kalimat yang mengandung frasa endosentrik atributif terdapat satu elemen pusat atau elemen utama, sedangkan elemen lainnya hanya pelengkap. Dalam frasa endosentrik atributif tidak dapat dihubungkan dengan kata hubung (dan/atau). Ramadhani (2018) mengungkapkan bahwa frasa endosentrik atributif terdiri atas elemen yang tidak sama, karena tidak memiliki kata penghubung dan/atau. Selain itu frasa endosentrik apositif adalah frasa yang memiliki kedudukan yang sama dan tidak bisa disisipi penghubung dan/atau. 
Frasa eksosentrik adalah gabungan kata seluruh elemen yang tidak memiliki perilaku sintaksis yang sama dengan keseluruhan komponen atau frasa yang tidak mempunyai distribusi yang sama dengan semua unsur pembentuk kata (Barutu, 2017). Menurut teori ini, frasa eksosentrik direktif adalah frasa yang tidak memiliki pendistribusian dengan semua elemenelemennya (Sofyan, 2015). Sementara itu, frasa eksosentrik nondirektif yaitu frasa yang gabungannya bukan preposisi; frasa ini ada yang berdistribusi komplementer, dan ada pula yang distribusi pararel dengan salah satu unsurnya. Surastina (2012) mengungkapkan bahwa frasa eksosentrik non-direktif memiliki elemen penggabung yaitu artikula yang terdiri atas dua kata atau lebih yang bergolongan kata benda, kata sifat, dan kata kerja. Dalam kebahasaan Indonesia ada beberapa jenis artikula, yaitu (1) artikula seperti sang dan hang, (2) artikula seperti para, kaum, umat, (3) artikula menominalkan seperti si (Siska, 2020).

Menurut Verhar (2014), berdasarkan struktur yang terbentuk dalam frasa, elemenelemen frasa endosentrik disusun atas kata, kata dan frasa, serta frasa dan frasa. Komponen struktur frasa endosentrik membentuk susunan di antaranya: DM (Diterangkan-Menerangkan), MD (Menerangkan-Diterangkan) dan MDM (Diterangkan-Menerangkan-Diterangkan). Fungsi diterangkan merupakan unsur pusat (UP), sedangkan fungsi menerangkan merupakan unsur atributnya (Atr).

Data penggunaan frasa diperoleh melalui analisis berita mengenai frasa endosentrik dan frasa ekosentrik sebagaimana dideskripsikan pada tabel 1 dan table 2 berikut ini.

Tabel 1 Penggunaan Frasa Endosentrik dalam Tajuk Rencana Solopos

\begin{tabular}{|c|c|c|c|}
\hline Kalimat & $\begin{array}{l}\text { Frasa Endosentrik } \\
\text { Koordinatif }\end{array}$ & $\begin{array}{c}\text { Frasa Endosentrik } \\
\text { Atributif }\end{array}$ & $\begin{array}{c}\text { Frasa Endosentrik } \\
\text { Apositif }\end{array}$ \\
\hline $\begin{array}{l}\text { Akuntabilitas ini mencakup } \\
\text { antikorupsi, dana desa, dan dana } \\
\text { kelurahan. }\end{array}$ & $\begin{array}{l}\text { antikorupsi, dana desa, } \\
\text { dan dana kelurahan }\end{array}$ & & \\
\hline $\begin{array}{l}\text { Tujuannya menguatkan kapasitas } \\
\text { OMS sehingga bisa bekerja sama erat } \\
\text { dan berkontribusi secara positif } \\
\text { terhadap pengembangan } \\
\text { pembangunan kabupaten/kota. }\end{array}$ & $\begin{array}{l}\text { pengembangan } \\
\text { pembangunan }\end{array}$ & & \\
\hline $\begin{array}{l}\text { Dengan demikian komunitas itu } \\
\text { sebagai wahana memetakan potensi } \\
\text { dan kelemahan OMS di daerah } \\
\text { masing-masing. }\end{array}$ & potensi dan kelemahan & & \\
\hline $\begin{array}{l}\text { Dalam konteks inilah program baru } \\
\text { dan sangat bagus seperti USAID } \\
\text { Madani ini menemukan relevansi dan } \\
\text { peran penting }\end{array}$ & & $\begin{array}{l}\text { program baru dan } \\
\text { sangat bagus }\end{array}$ & \\
\hline $\begin{array}{l}\text { Program USAID Madani menjalin } \\
\text { kerja sama peningkatan kapasitas }\end{array}$ & & kerja sama & \\
\hline $\begin{array}{l}\text { Termasuk peningkatan kualitas } \\
\text { pelayanan publik. }\end{array}$ & & pelayanan publik & \\
\hline
\end{tabular}




\begin{tabular}{|c|c|}
\hline $\begin{array}{l}\text { Sekitar satu dekade terakhir OMS di } \\
\text { Kota Solo dan kabupaten lain di } \\
\text { sekitarnya boleh dikatakan mati suri, } \\
\text { sedang menunjukkan aktivitas yang } \\
\text { kurang mendukung pewujudan } \\
\text { akuntabilitas pemerintahan. }\end{array}$ & $\begin{array}{l}\text { kabupaten lain di } \\
\text { sekitarnya boleh } \\
\text { dikatakan mati suri, } \\
\text { sedang } \\
\text { menunjukkan } \\
\text { aktivitas yang } \\
\text { kurang mendukung }\end{array}$ \\
\hline $\begin{array}{l}\text { Program ini, salah satu cara yang } \\
\text { dimanfaatkan untuk konsolidasi } \\
\text { masyarakat sipil. }\end{array}$ & $\begin{array}{l}\text { program ini, salah } \\
\text { satu cara yang } \\
\text { dimanfaatkan }\end{array}$ \\
\hline
\end{tabular}

Berdasarkan tabel di atas, diketahui penggunaan frasa endosentrik dalam Tajuk Rencana Solopos yang berjudul "Konsilidasi dan Pemberdayaan Organisasi Masyarakat Sipil”. Terdapat 8 contoh frasa endosentrik. Penggunaan frasa endosentrik koordinatif sebanyak 3 frasa, penggunaan frasa endosentrik atributif sebanyak 3 frasa, dan penggunaan frasa endosentrik apositif sebanyak 2 frasa.

Pada tabel 1 terdapat tiga frasa endosentrik koordinatif yaitu antikorupsi, dana desa, dan dana kelurahan; pengembangan pembagunan; potensi dan kelemahan. Ketiga frasa tersebut adalah frasa endosentrik koordinatif yaitu frasa yang unsur-unsurnya setara, dapat dihubungkan dengan kata dan.

Pada tabel 1 juga terdapat tiga frasa endosentrik artibutif yaitu program baru, kerja sama, pelayanan publik. Elemen frasa endosentrik atributif ditandai dengan dicetak tebal merupakan unsur utama, sedangkan elemen lainnya merupakan elemen atributif yang menjelaskan unsur utama. Ketiga frasa tersebut digolongkan frasa endosentrik atributif yaitu frasa yang elemen-elemennya tidak sama sehingga tidak dapat disisipi kata dan, atau.

Pada tabel 1 juga terdapat dua frasa endosentrik apositif yaitu kabupaten lain di sekitarnya boleh dikatakan mati suri, sedang menunjukkan aktivitas yang kurang mendukung; dan program ini, salah satu cara yang dimanfaatkan. Dalam frasa endosentrik apositif ada elemen yang diterangkan atau elemen inti yakni kabupaten lain di sekitarnya boleh dikatakan mati suri, dan program ini. Ada juga unsur yang dapat saling mengantikan yaitu sedang menunjukkan aktivitas yang kurang mendukung, dan salah satu cara yang dimanfaatkan. Kedua unsur ini memiliki distribusi yang sama dengan frasa yang dimaksud.

Hal baru dari penelitian ini yaitu menganalisis struktur terbentuknya frasa endosentrik. Berdasarkan data tabel 1 ditemukan struktur berikut ini. Frasa kata benda(FN)/ kata benda(N) + konjungsi+ frasa kata benda(FN)/ kata benda(N) berjumlah 1 data yaitu terdapat pada kata antikorupsi, dana desa, dan dana kelurahan. Frasa kata kerja(FV)/ kata kerja(V) + frasa kata kerja(FV)/ kata kerja(V) berjumlah 4 data yaitu terdapat pada kata pengembangan pembangunan; menjalin kerja sama; mati suri, sedang menunjukan; salah atu cara yang dimanfaatkan. Frasa kata kerja(FV)/ kata kerja(V) + konjungsi + frasa kata kerja(FV)/ kata $\operatorname{kerja}(\mathrm{V})$ berjumlah 1 data yakni terdapat pada kata memetakan potensi dan kelemahan. Frasa kata kerja $(\mathrm{FV}) /$ kata kerja $(\mathrm{V})+$ frasa kata benda(FN)/ kata benda(N) berjumlah 1 data yaitu terdapat pada kata pelayanan public. Frasa kata benda(FN)/ kata benda(N) + kata sifat(A) berjumlah 1 data yaitu terdapat pada kata program baru. 
Dari pengkajian yang dilakukan dapat dibuktikan bahwa frasa endosentrik dibentuk dari kelas kata yang dapat mengalami proses morfologis seperti frasa kerja sama, potensi, pengembangan pembangunan. Kata kerja sama, potensi dapat mengalami proses morfologis menjadi bekerja sama, berpotensi. Kata pengembangan pembangunan merupakan proses morfologis dari kata kembang dan bangun. Kata tersebut dapat dilakukan proses morfologi menjadi berkembangnya pembangunan.

Tabel 2 Penggunaan Frasa Eksoentrik dalam Tajuk Rencana Solopos

\begin{tabular}{|c|c|c|}
\hline Kalimat & $\begin{array}{l}\text { Frasa Eksosentrik } \\
\text { Direktif }\end{array}$ & $\begin{array}{l}\text { Frasa Eksosentrik } \\
\text { Non-Direktif }\end{array}$ \\
\hline $\begin{array}{l}\text { Keberlanjutan OMS dengan pemerintah } \\
\text { kabupaten/kota di daerah provinsi. }\end{array}$ & di daerah provinsi & \\
\hline $\begin{array}{l}\text { Program Madani yang didanai bantuan pemerintah } \\
\text { Amerika Serikat untuk pembangunan. }\end{array}$ & untuk pembangunan & \\
\hline $\begin{array}{l}\text { OMS di Kota Solo dan Kabupaten Boyolali harus } \\
\text { memanfaatkan program ini untuk memberdayakan. }\end{array}$ & untuk pemberdayaan & \\
\hline $\begin{array}{l}\text { Program ini harus dimanfaatkan dari konsolidasi antar } \\
\text { masyarakat sipil. }\end{array}$ & $\begin{array}{l}\text { dari konsalidasi antar } \\
\text { masyarkat sipil }\end{array}$ & \\
\hline $\begin{array}{l}\text { Sudah saatnya pula pemerintah daerah menjadikan } \\
\text { OMS sebagai mitra pengawas. }\end{array}$ & sebagai mitra pengawas & \\
\hline $\begin{array}{l}\text { Dengan kata lain para anggota OMS atau masyarakat } \\
\text { sipil secara umum adalah organisasi masyarakat yang } \\
\text { didirikan secara sukarela yang berbeda dengan } \\
\text { aparatur-aparatur pemerintahan. }\end{array}$ & & para anggota \\
\hline Upaya mendukung pembangunan di daerah. & di daerah & \\
\hline
\end{tabular}

Tabel 2 di atas mendeskripsikan frasa eksosentrik dalam Tajuk Rencana Solopos yang berjudul "Konsilidasi dan Pemberdayaan Organisasi Masyarakat Sipil". Ditemukan sebanyak 6 frasa eksosentrik direktif dan frasa eksosentrik non-direktif sejumah 1 frasa.

Pada tabel 2 terdapat enam frasa eksosentrik direktif yaitu terdapat pada kata di daerah provinsi, untuk pembangunan, untuk pemberdayaan, dari konsalidasi antar masyarakat sipil, sebagai mitra pengawas, dan di daerah. Data tersebut membuktikan bahwa frasa eksosentrik direktif ialah frasa yang memiliki preposisi, seperti di, untuk, dan sebagai.

Pada tabel 2 terdapat satu frasa eksosentrik non-direktif yaitu terdapat pada kata para anggota. Data tersebut menunjukan bahwa frasa eksosentrik non-direktif yaitu frasa yang memiliki preposisi para.

Hal baru dari penelitian ini yaitu menganalisis struktur terbentuknya frasa eksosentrik. Berdasarkan data pada tabel 2, dapat diketahui struktur frasa eksosentrik. Struktur preposisi + frasa kata benda(FN)/ kata benda(N)+ frasa kata benda(FN)/ kata benda(N) berjumlah 1 data terdapat pada kata di daerah provinsi. Struktur preposisi + frasa kata kerja(FV)/ kata kerja(V) berjumlah 2 data terdapat pada kata untuk pembangunan dan untuk pemberdayaan. Struktur preposisi + kata benda $(\mathrm{N})$ berjumlah 3 data terdapat pada kata dari konsolidasi masyarakat 
sipil, sebagai mitra pengawas dan para anggota. Struktur preposisi + kata benda( $\mathrm{N})$ terdapat 1 data pada kata di daerah. Frasa eksosentrik terdapat unsur perangkai dan unsur utama. Unsur perangkai berupa preposisi seperti di, untuk, sebagai, dari.

Perbedaan penelitian ini dengan penelitan terdahulu adalah penelitian terdahulu hanya menganalisis struktur frasa berdasarkan kesetaraan distribusi tanpa menghubungkan dan memperjelas dengan berdasarkan kategori kata atau kelas kata. Penelitian ini memiliki kesamaan menganalisis frasa berdasarkan distribusi dengan memperhatikan konjungsi penghubung (dan/atau) dan menentukan struktur pembentuk frasa tersebut.

Penelitian ini menggungkap penemuan baru yaitu sintaksis dalam bahasa Indonesia dan bahasa Inggris memiliki kesamaan struktur frasa. Hal ini dari struktur frasa yakni penggunaan penanda bahasa Inggris seperti kata verb, noun, adjektiva. Hal ini karena bahasa Indonesia dan bahasa Inggris memiliki konsep yang sama mengenai sintaksis yaitu ilmu tata kalimat yang menguraikan hubungan antar usur pembentuk sebuah kalimat. Yang membedakan hanya terletak pada penggunaan bahasa asing dan bahasa Indonesia.

Manfaat penelitian ini yaitu memperkaya khasanah ilmu pengetahuan dalam pengkajian ilmu sintaksis, terutama mengenai frasa. Secara praktis, dapat mengurangi masalah dalam penentuan kelompok frasa berdasarkan kesetaraan distribusinya, yang berguna bagi pengguna bahasa Indonesia, terutama dalam pembentukan teks berita. Penelitian ini dapat juga menjadi referensi kepada peneliti lain untuk melakuan menggolongkan frasa atau menganalisis struktur frasa berdasarkan sistem kesetaraan distribusinya.

\section{SIMPULAN}

Berdasarkan hasil penelitian dan pembahasan, dapat disimpulkan bahwa pada Tajuk Rencana Solopos yang berjudul "Konsilidasi dan Pemberdayaan Organisasi Masyarakat Sipil" terdapat 15 frasa berdasarkan kesetaraan distribusi. Frasa endosentrik koordinatif berjumlah 3 frasa, frasa endosentrik atributif sebanyak 3 frasa, dan frasa endosentrik apositif sebanyak 2 frasa. Terdapat penggunaan frasa eksosentrik, dengan rincian frasa eksosentrik direktif sebanyak 6 frasa, penggunaan frasa eksosentrik non-direktif sebanyak 1 frasa. Diperoleh juga struktur frasa pada frasa endosentrik yaitu FN/N + konj + FN/N, FV/V + FV/V, FV/V + konj+FV/V, FV/V + FN/, FN/N + A serta terdapat struktur frasa eksosentrik yaitu preposisi + $\mathrm{FN} / \mathrm{N}+\mathrm{FN} / \mathrm{N}$, preposisi $+\mathrm{FV} / \mathrm{V}$, preposisi $+\mathrm{N}$.

Berdasarkan simpulan yang telah dipaparkan di atas, dapat diajukan saran yaitu penelitian ini perlu dilanjutkan dengan bahasa yang lebih spesifik terutama berkaitan dengan frasa endosentrik dan frasa eksosentrik. Peneliti yang akan melakukan penelitian disarankan untuk mencari dan membaca referensi lain lebih banyak, terutama yang berkaitan dengan frasa endosentrik dan frasa eksosentrik agar hasil penelitian selanjutnya akan semakin baik. Melakukan klasifikasi frasa lebih baik dilakukan per paragraf supaya lebih efisien karena bila per jenis frasa akan membuang waktu secara percuma. Bagi dunia pendidikan, penelitian ini dapat digunakan sebagai wahana belajar para mahasiswa untuk lebih mengenal jenis frasa berdasarkan kesetaraan distribusi dan struktur frasanya. 


\section{DAFTAR PUSTAKA}

Barutu, N. S. 2017. "Analisis Kesalahan Struktur Frasa Dalam Teks Eksposisi Siswa Kelas X SMA Negeri 15 Medan Tahun Pembelajaran 2016/2017". Basastra, 6 (3), 169-176.

Bastian, A. A. 2018. "Analisis Pemakaian Frase Bahasa Indonesia dalam Berita Online Bola.Net Bulan April 2015". Skripsi. Surakarta: Program Studi Pendidikan Bahasa Indonesia, FKIP, Universitas Muhammadiyah Surakarta.

Dani, H. W. 2015. "Penggunaan Frasa Dalam Karangan Narasi Pada Siswa Kelas X Sma Negeri 4 Tangerang Selatan". Skripsi. Jakarta: Fakultas Ilmu Tarbiyah dan Keguruan, Universitas Negeri Islam Syarif Hidayatullah.

Maharani, K. 2020. "Kesalahan Frasa Dalam Karangan Narasi Sugestif Karya Siswa Kelas VII8 MTsN 1 Blitar". Skripsi. Tulungagung: Fakultas Ilmu Tarbiyah dan Keguruan, IAIN Tulungagung.

Melani, S., dkk. 2019. "Analisis Frasa Pada Surat Kabar Harian Rakyat Bengkulu". Jurnal Ilmiah KORPUS, 3 (2): 210-220.

Ningsih, R. 2016. "Analisis Frasa Eksosentrik Dan Endosentrik Rubrik Berita "Puan" Dalam Surat Kabar Tribunnews Edisi Februari 2016". Skripsi. Tanjungpinang: Jurusan Pendidikan Bahasa dan Sastra Indonesia, FKIP, Universitas Maritim Raja Ali Haji.

Nisa, K. 2018. "Analisis Kesalahan Berbahasa Tiga Berita Pilihan Pada Surat Kabar Sinar Indonesia Baru Edisi November 2017". Jurnal Komunitas Bahasa, 6 (1): 54-61.

Ramadhani, C. 2018. "Penggunaan Frasa Endosentrik Apositif Pada Wacana Berita Di Rubrik Go Cakrawala". Skripsi. Makasar: Jurusan Pendidikan Bahasa dan Sastra Indonesia, FKIP, Universitas Muhammadiyah.

Rahayu, S. 2019. "Penggunaan Frasa Endosentrik Apositif Dalam Karangan Wacana Berita". Algazali Journal, 1 (2): 181-185, doi: 10.24567/aijer.v1i2.315.

Ramlan. 2005. Ilmu Bahasa Indonesia Sintaksis. Yogyakarta: C.V. Karyono.

Sakinah, N. 2017. "Frasa Endosentris Sistem Distribusi Dalam Koran Fajar". Skripsi. Makasar: Jurusan Pendidikan Bahasa dan Sastra Indonesia, FKIP, Universitas Muhammadiyah.

Siska, S dkk. 2020. "Analisis Frasa Teks Cerita Pendek Karya Siswa Kelas XI SMK Negeri 1 Padang Panjang." Jurnal Pendidikan Bahasa dan Sastra Indonesia, 8 (3): 393-339.

Sofyan, A. N. 2015. Frasa Direktif Yang Berunsur Di, Dari, Dan Untuk Dalam Bahasa Indonesia: Kajian Sintaktis Dan Semantis”, Jurnal Sosiohumaniora. 17 (3): 262-266, doi: 10.24198/sosiohumaniora.v17i3.8344

Suhardi. 2013. Dasar-Dasar Ilmu Sintaksis Bahasa Indonesia. Yogyakarta: Ar-Ruzz.

Sudiarni. 2012. “Analisis Struktur Frasa Bahasa Indonesia Dalam Rubrik Opini Harian Fajar Makassar”. Skripsi. Makasar: Universitas Muhammadiyah Makassar.

Surastina. 2012. “Frasa Dalam Bahasa Indonesia”. Jurnal Lentera, 2: 9-17.

Verhaar. 2014. Asas-Asas Linguistik Umum. Yogyakarta: Gadjah Mada University Press. 